\title{
Improving the Motivation and Learning Outcomes of Learners Through Scientific Approach in SDN Citepus 01
}

\section{Sariyah}

SD Negeri Citepus 01

sariyahjeruklegi@gmail.com

\section{Article History}

accepted 14/11/2020

approved $21 / 11 / 2020$

published 26/11/2020

\begin{abstract}
The purpose of this research is to increase the motivation and learning outcomes of learners in the material PPKn pancasila first practice sila using scientific shortata can improve the motivation and learning outcomes of learners. In the first cycle showed learning motivation (60\%) and learning outcomes (55\%). In Cycle II, it is able to increase learning motivation (75\%)and learning outcomes (80\%). In Sikluslll is able to increase learning motivation (95\%) and learning outcomes (95\%). In The First Cycle, Learning completeness reached 55\% with an average value of 70.01 . cycle II reaches $80 \%$ with an average value of 76.15 . In Cycle III it reaches $95 \%$ with an average value of 96.00 .
\end{abstract}

Keywords: Scientific approach, learning motivation, learning outcomes

\begin{abstract}
Abstrak
Tujuan dari penelitian ini adalah untuk meningkatkan motivasi dan hasil belajar peserta didik pada materi PPKn, Pancasila pengamalan sila pertama menggunakan pendekatan saintifik dapat meningkatkan motivasi dan hasil belajar peserta didik. Pada siklus I menunjukan motivasi belajar $(60 \%)$ dan hasil belajar (55\%). Pada Siklus II mampu meningkatkan motivasi belajar $(75 \%)$ dan hasil belajar (80\%). Pada Siklus III mampu meningkatkan motivasi belajar (95\%) dan hasil belajar (95\%). Pada Siklus I ketuntasan Belajar mencapai $55 \%$ dengan nilai rata-rata 70,01. pada siklus II mencapai $80 \%$ dengan nilai rata-rata 76,15 . Pada Siklus III mencapai $95 \%$ dengan nilai rata - rata 96,00 .
\end{abstract}

Kata kunci: Pendekatan saintifik, motivasi belajar, hasil belajar

Social, Humanities, and Education Studies (SHEs): Conference Series https://jurnal.uns.ac.id/shes

p-ISSN 2620-9284

e-ISSN 2620-9292

This work is licensed under a Creative Commons Attribution-ShareAlike 4.0 International License. 


\section{PENDAHULUAN}

Pendidikan saat ini seharusnya membentuk peserta didik yang mampu menghadapi era globalisasi, misalnya masalah lingkungan hidup, kemajuan teknologi informasi. Peserta didik saat ini harus terbiasa mencari informasi sendiri, mampu mengamati, mengidentifikasi, mengolah informasi dan mampu mengkomunikasikannya. Oleh karena itu peserta didik pada jenjang sekolah dasar harus dibekali dengan pengetahuan, sikap dan ketrampilan dalam mengolah informasi.

Kenyataan dilapangan motivasi peserta didik masih lemah, sehingga pengaruh terhadap hasil pembelajaran. Pembelajaran adalah proses interaksi antara peserta didik dengan pendidik, sumber belajar serta media yang digunakan. Motivasi belajar yaitu apasaja yang dapat menumbuhkan minat siswa untuk belajar dan yang membuat siswa untuk selalu berminat untuk belajar.

Hal ini menjadi pertimbangan pendidik dalam menentukan model pendekatan Pendekatan sebelumnya menjadi tolak ukur untuk menentukan model pendekatan yang nantinya dapat meningkatkan motivasi dan hasil peserta didik.

Pendekatan yang tepatakan berdampak pada pelaksanaan pembelajaran. Karena pendekatan akan mampu membawa peserta didik aktif dan termotivasi dalam mengikuti pembelajaran yang dilakukan secara daring. Dalam proses pembelajaran pendidik adalah fasilitator yang menstransfer materi yang akan disampaikan. Sehingga peserta didik harus memiliki pendekatan yang tepat agar materi yang disampaikan selalu diingat oleh peserta didik.

Solusi dari permasalahan diatas yaitu dengan peningkatan motivasi belajar akan mampu meningkatkan hasil belajar peserta didik. Melalui pendekataan saintifik akan mampu membawa perubahan kepada peserta didik dalam mengikuti pembelajaran. Pendekatan saintifik adalah pembelajaran yang menekankan pada pemberian pengalaman secara langsung baik melalui melalui media daring berupa slide gambar atau sumber belajar lainnya, yang mana anak dapat menganalisis/mengamati, mampu bertanya, mengolah informasi, mengumpulkan data dan menarik kesimpilan/mengkomuikasikannya.

Berdasarkan masalah latar belakang diatas peneliti mengambil judul "Peningkatan Motivasi Dan Hasil Peserta Didik Melalui Pendekatan Saintifik Pada Materi PPKn Pengamalan Pancasila Sila Pertama Kelas 1 SD Negeri Citepus 01 Tahun Pelajaran 2020/2021." Berdasarkan latar belakang diatas peneliti merumuskan permasalahan sebagai berikut "Apakah pendekatan Saintifik mampu meningkatkan motivasi dan hasil peserta didik pada materi PPKn Pengamalan Sila Pertama Kelas 1 SD Negeri Citepus 01?"

\section{METODE}

Penelitian ini adalah penellitian adalah penelitian tindakan kelas (Classroom Action Research) dengan menerapkan Pendekatan Saintifik. Menurut Kurt Lewin dalam Kunandar(2011:42) penelitian tindakan kelas ini terdiri dari empat tahapan dasar yaitu perencanaan (planning), pelaksanaan (acting), pengamatan (observing), dan refleksi (reflecting). Analisis penelitian ini adalah analisis deskriptif, kuantitatif kualitatif dimana dalam peneliatian ini selain penyajian hasil berupa data maupun angka peneliti juga menentukan bagaimana cara pengolahan hasil penelitian yakni dengan membuat analisisnya dengan menerapkan Pendekatan Saintifik. Penelitian ini dilaksanakan pada peserta didik kelas I SD Negeri Citepus 01 Tahun Pelajaran 2020/2021 selama tiga siklus secara daring menggunakan aplikasi Zoom Meet. Siklus I dilaksanakan pada tanggal 16 November 2020. Siklus ke II dilaksanakan pada tanggal 24 November 2020. Dan Siklus 3 dilaksanakan pada tanggal 04 Desember 2020. Teknik pengumpulan data yang dilakukan dengan observasi dan tes, baik pre test maupun post test. Observasi meliputi observasi keterlaksanaan metode Pendekatan Saintifik, 
sikap peserta didik dan ketrampilan. Untuk hasil belajar menggunakan tes melalui Google form.

\section{HASIL DAN PEMBAHASAN}

Kondisi awal proses pembelajaran siswa diketahui dari data motivasi dan hasil belajar siswa kelas I SD Negeri Citepus 01 dan observasi selama pembelajaran. Dari pengumpulan data tersebut diketahui bahwa motivasi dan hasil belajar siswa kelas I SD Negeri Citepus 01 masih tergolong rendah. Kurangnya keterlibatan siswa dalam proses pembelajaran membuat siswa menjadi bosan dan pasif dalam mengikuti pembelajaran.

Berdasarkan observasi pembelajaran, diketahui bahwa guru masih menerapkan. Pendekatan pembelajaran konvensional menjadikan guru lebih dominan dalam kegiatan pembelajaran. Siswa hanya sebagai objek pembelajaran, sehingga kurang adanya keterlibatan siswa dalam pembelajaran. Dalam proses pembelajaran siswa hanya sebagai penerima informasi dari guru. Dampaknya pemahaman siswa menjadi kurang sehingga motivasi dan hasil belajar siswa tergolong rendah. Hasil belajar siswa sebelum dilakukan tindakan dapat dilihat dari tabel berikut.

Tabel 1. Rekapitulasi peningkatan motivasi belajar peserta didik dari siklus awal sampai siklus III.

\begin{tabular}{cccccc}
\hline & & \multicolumn{2}{c}{ Peserta didik yang } & \multicolumn{2}{c}{ Peserta didik yang } \\
No. & Uraian & \multicolumn{2}{c}{ belum termotivasi } & \multicolumn{2}{c}{ sudah termotivasi } \\
& & Frekuensi & $\%$ & Frekuensi & $\%$ \\
\hline 1. & Studi Awal & 12 & 60 & 8 & 40 \\
2. & Siklus I & 8 & 40 & 12 & 60 \\
3. & Siklus II & 5 & 25 & 15 & 75 \\
4. & Siklus III & 1 & 5 & 19 & 95 \\
\hline
\end{tabular}

Berdasarkan data diatas dapat kita lihat peningkatan motivasi dari setiap peserta didik tiap silkus sebagian besar mengalami penigkatan. Perubahan motivasi dapat diuraikan sebagai berikut:

1. Peserta didik yang belum termotivasi sebagai berikut:

a) Pada studi awal, peserta didik yang kurang termotivasi sebanyak 12 peserta didik dari 20 peserta didik (60\%).

b) Pada siklus I, peserta didik yang kurang termotivasi sebanyak 8 peserta didik dari 20 peserta didik(40\%).

c) Pada siklus II, peserta didik yang kurang termotivasi sebanyak 5 peserta didik dari 20 peserta didik(25\%).

d) Pada Siklus III, peserta didik yang kurang termotivasi sebanyak 1 peserta didik dari 20 peserta didik (5\%)

2. Peserta didikyang sudah termotivasi dalam belajar

a) Pada studi awal, peserta didik yang sudah termotivasi sebanyak 8 peserta didik dari 20 peserta didik(40\%).

b) Pada Siklus 1, peserta didik yang sudah termotivasi sebanyak 12 peserta didik dari 20 peserta didik(60\%).

c) Pada Siklus II, peserta didik yang sudah termotivasi sebanyak 15 peserta didik dari 20 peserta didik(75\%).

d) Pada Siklus III, peserta didik yang sudah termotivasi sebanyak 19 peserta didik dari 20 peserta didik(95\%)

e) 
Tabel 2. Rekapitulasi peningkatan hasil belajar peserta didik dari siklus awal sampai siklus III.

\begin{tabular}{llcccc}
\hline & & Uraian & \multicolumn{2}{c}{$\begin{array}{c}\text { Peserta didik yang } \\
\text { belum termotivasi }\end{array}$} & \multicolumn{2}{c}{$\begin{array}{c}\text { Peserta didik yang } \\
\text { sudah termotivasi }\end{array}$} \\
& & Frekuensi & $\%$ & Frekuensi & $\%$ \\
\hline 1. & Studi Awal & 12 & 60 & 8 & 40 \\
2. & Siklus I & 8 & 40 & 12 & 60 \\
3. & Siklus II & 5 & 25 & 15 & 75 \\
4. & Siklus III & 1 & 5 & 19 & 95 \\
\hline
\end{tabular}

Berdasarkan data diatas dapat kita lihat hasil perubahan nilai yang dicapai peserta didik dari tiap siklus sebagian besar mengalami kenaikan.

Perubahan hasil belajar dapat diuraikan sebagai berikut :

1. Pada studi awal peserta didik yang belum tuntas belajar sebanyak 14 peserta didik dari 20 peserta didik $(70 \%)$

2. Pada Siklus 1 peserta didik yang belum tuntas belajar sebanyak 9 peserta didik dari 20 peserta didik(45\%)

3. Pada siklus 2 peserta didik yang belum tuntas belajar sebanyak 4 peserta didik dari 20 peserta didik (20\%)

4. Pada Siklus 3 peserta didik yang belum tuntas belajar sebanyak 1 peserta didik dari 20 peserta didik $(5 \%)$

Siswa yang sudah tuntas belajar :

1. Pada Studi awal, peserta didik yang sudah tuntas belajar sebanyak 6 peserta didik dari 20 peserta didik (30\%).

2. Pada siklus 1 , peserta didik yang tuntas belajar sebanyak 11 peserta didik dari 20 peserta $\operatorname{didik}(55 \%)$.

3. Pada siklus 2 , peserta didik yang tuntas belajar sebanyak 16 peserta didik dari 20 peserta $\operatorname{didik}(80 \%)$.

4. Pada siklus 3 , peserta didik yang tuntas belajar sebanyak 19 peserta didik dari 20 peserta didik (95\%).

Dalam 3 siklus perbaikan pembelajaran dengan menekankan pembelajaran melalui pendekatan saintifik motivasi dan hasil belajar siswa mengalami peningkatan. Peningkatan ini dapat kita lihat dari peningkatan motivasi dan hasil belajar peserta didik dari studi awal baru mencapai 40\% (untuk motivasi). Setelah diadakan perbaikan pada siklus I motivasi belajar mencapai $60 \%$,pada siklus II mencapai $75 \%$ dan pada siklus 3 mencapai 95\%. Peningkatan hasil belajar peserta didik juga mengalami peningkatan, pada studi awal baru mencapai $30 \%$, pada siklus I mencapai $55 \%$ dan pada siklus II mencapai $85 \%$ dan pada siklus 3 mencapai 95\%. Bimbingan dan motivasi guru mempengaruhi terhadap peningkatan motivasi belajar dan hasil belajar peserta didik.

\section{SIMPULAN}

Berdasarkan pelaksanaan hasil penelitian dan pembahasan yang diperoleh dari studi awal sampai dengan siklus kedua dapat disimpukan bahwa :

Pendekatan saintifik dapat meningkatkan motivasi peserta didik di kelas I SD Negeri Citepus 01. Hal ini terlihat dari lembar pengamatan yang dilakukan selama penelitian. Sebelum penelitian dilakukan motivasi belajar peserta didik masih rendah. Guru belum menerapkan pendekatan saintifik dalam melaksanakan pembelajaran materi Pancasila Pengamalan Sila Pertama sehingga pembelajaran cenderung membosankan karena pembelajaran hanya searah saja guru menjelaskan dan siswa mendengarkan. Namun, setelah dilakukan pendekatan saintfik dalam pembelajaran di 
kelas I SD Negeri Citepus 01 berdasarkan data-data yang diperoleh terbukti bahwa pendekatan saintifik dapat meningkatakan motivasi peserta didik. Pembelajaran pun terlihat lebih menarik dan menyenangkan aktifitas peserta didik lebih dominan dari pada guru. Peserta didik yang awalnya terlihat malas mengikuti pembelajaran menjadi bersemangat, hal ini berdampak positif terhadap pemahaman pesrta didik terhadap materi.

Pendekatan saintifik dapat meningkatkan hasil belajar peserta didik di kelas I SD Negeri Citepus 01. Hal ini dibuktikan dari hasil penelitian menunjukan bahwa pada saat studi awal hanya ada 6 peserta didik yang mampu masuk kategori baik atau mendapatkan nilai 70, kemudian 11 peserta didik mendapatkan nilai 60 dan 4 peserta didik mendapat nilai 50. Nilai siswa yang mencapai ketuntasan hanya dan 6 atau hanya $30 \%$ saja dengan nilai rata-rata 62 . Kemudian setelah menggunakan pendekatan saintifik pada siklus satu nilai rata-rata menjadi 70,00 dan peserta didik yang mencapai ketuntasan bertambah menjadi 11 peserta didik atau $55 \%$. Selanjutnya di siklus kedua nilai rata-rata menjadi 76,15 , dengan peserta didik yang mencapai ketuntasan menjadi 16 atau $80 \%$. Ketuntasan pada siklus ketiga menjadi 19 peserta didik atau 95\%. Berdasarkan hasil analisis data dapat disimpulkan bahwa penggunaan pendekatan saintifik dapat meningkatkan motivasi belajar dan hasil belajar peserta didik di kelas I SD Negeri Citepus 01 Kecamatan Jeruklegi Kabupaten Cilacap.

\section{DAFTAR PUSTAKA}

Asrori, Mohammad. 2009. Penelitian Tindakan Kelas. Bandung: CV Wacana Prima Dalyono M, Psikologi Pendidikan, (Jakarta : Rineka Cipta, 2005)

Daryanto. 2014. Pendekatan Pembelajaran Saintifik Kurikulum 2013. Yogyakarta : Penerbit Gava Media.

Hosnan, M. 2014. Pendekatan Saintifik dan Kontekstual dalam Pembelajaran Abad 21. Bogor: Ghalia Indonesia.

Karar, E. E. dan Yenice, N. 2012. The investigation of scientific process skill level of elementary education 8th grade students in view of demographic features. Procedia Social and Behavioral Sciences.

Majid, Abdul. 2014. Pembelajaran Tematik Terpadu. Bandung: Remaja Rosdakarya. Ngalim Forwanto, Psikologi Pendidikan, (Bandung : Remaja Rosdakarya ,1990), h.72 Rusman. 2015. Pemebelajaran Tematik Terpadu. Jakarta: Raja Grafindo Persada. 